ology for more than a century, that provided the correlation Wheeler needed in order to extend his chronological datum-line across southern India - a correlation that would prove no more accurate for Wheeler than it had been for others.

As with Pitt Rivers some 60 years earlier (Pitt Rivers 1889), Wheeler's critique was that without accurate stratigraphic measurement, reliable association was not possible. For both Pitt Rivers and Wheeler, the primary purpose of 'threedimensional recording' was that it ensured accurate sequence and association - not the accurate dating of the deposits, their identification or their function. These latter aims, more familiar to us today as the self-evident purpose

\section{References}

BADÉ, W.F. 1929. A manual of excavation in the Near East. Berkeley (CA): University of Califormia Press.

HAWKES, J.1984. Mortimer Wheeler: adventurer in archaeology. London: Abacus.

PETRIE, W.M.F. 1904. Methods and aims in archacology, London: Macmillan.

PITT-RIVERS, A.H.L.F. 1889. Excavations in Granbourne Chase. Privately printed.

ROY, S. 1996. The story of Indian archaeology, 1784-1947. New Delhi: Archaeological Survey of India. of stratigraphy, were in reality secondary outcomes of the method for Wheeler. As he would write 10 years later in Archaeology from the Earth, 'The need for re-establishing the relative sequence of ancient cultures or cultural episodes, if we are to begin to understand their interactions and values, is self-evident, and stratigraphical excavation ... is a primary means to that end' (Wheeler 1954: 38). But, if universal relative sequences are the goal, stratigraphic excavation can only ensure accurate association and sequence, and their extension beyond the site requires in fact more traditional methods.

Acknowledgements. I would like to thank the Archaeological Survey of India and in particular the late Ajai Shankar for their generous assistance and access to their archives.

WHEELER, R.E.M. 1948. Technical Section: 4.-Further notes on digging and recording. Ancient India (4: 311-21).

1954. Archaeology from the earth. Oxford: Clarendon Press.

1956. Still digging. London: Readers Union.

WHEELER, R.E.M., A. GHOSH \& K. DEVA, 1946. Arikamedu: an Indo-Roman trading-station on the East Coast of India, Ancient India 2: 17-124.

WOOLLEY, L. 1939. A report on the work of the Archaeological Survey of India. Delhi.

\title{
On the international roots of prehistory
}

\author{
MARC-ANTOINE KAESER *
}

Key-words: institutionalization, nationalism, antiquarianism, cultural evolution, international congress of prehistory, archives, history of archaeology

\section{Introduction}

In recent years, considerable attention has been dedicated to the involvement of archaeology (and most notably prehistory) with nationalism. The probable causes of this recent fashion $^{1}$ need not concern us here, but the movement itself is cortainly welcome, testifying to the reflection of archaeologists on their own practices and those of their predecessors. For historians, this trend is quite welcome insofar as it contributes to a general renaissance of in-

1 This tendency results as much from the ideological, political and economical changes of the last decade, as from theoretical considerations in contemporary archaeology (seo Hamilakis 1996; Kohl 1998; Gramsch 1999; Kaeser 2000a). terest in the past of the discipline. However, a more careful examination of this historiography leads us to some caution about its significance.

Firstly, the majority of these historical studies adopt an internalist perspective which, combined with their self-declared reflexiveness, confers on them a rather presentist character. The result belongs to some sort of 'history of ideas' which has been embellished with a few sociological insights of varying subtlety. In line with the old sociology of science, social factors are only invoked to explain the 'errors' of archaeology. Such errors, therefore, always seem to be accounted for by external and, by definition, pernicious influences. As a consequence,

* Swiss National Museum, Department of Archaeology, Hardturmstr. 185, CH-8005 Zürich, Switzorland. ma.kaeser@bluewin.ch ANTIQUITY 76 (2002): 170-77 
our discipline always escapes unscathed: its 'purity' is not at stake, simply because these are always 'society' and 'politics' that abuse it.

Moreover, most attention is given to the interprefations of the past, not to archaeological research as such. It is not the historical practice of the discipline that is then under consideration, but rather its thematic scope - which is quite a different matter. However, conceptions of identity based on the past are by no means the exclusive preserve of archaeology. No one has been waiting for the birth of our discipline in order to gloat over the 'heroic deeds of our glorious ancestors'. As a matter of fact, in terms of nationalism, archaeology has entered quite late into the fray, on a terrain that was by thon already demarcated. ${ }^{2}$

\section{Is archaeology intrinsically nationalist?}

The wealth of historical case-studies suggest that from its origins, archaeology, and more specifically prehistoric archaeology, has been strictly dependent on the emergence of national ideologies. The general impression is clear: were it not for the dynamics of modern nationalism, the argument goes, our discipline would never have emerged. This inference is mostly implicit but becomes at times quite explicit, e.g. when Díaz-Andreu \& Champion (1996: 3) state that 'nationalism .... is deeply embedded in the very concept of archaeology, in its institutionalisation and its development'. Certainly, this sort of statemont allows the authors to develop entirely respectable deontological considerations, but it seems to me that, leaving ethics behind and turning to epistemology, such statements may lead the scientific community into an unwarranted feeling of absolved responsibility. If archaeology were really linked by its essence to nationalism, archaeologists could simply oversee their own formal actions, without questioning their epistemological choices. True, the involvement of archaeology with nationalism is unmistakable: our discipline has paid considerable lip-service to politics, and has received many of its institutional structures in return. However, this compromise is not an

\footnotetext{
$2 C$. Kaeser (2000b). In this respect, it seems more usefil] to research how earlier representations have been adapted in archaeological discourse, by distinguishing as far as possible between the production, diffusion and reception of these representations (taking into account that these three stages are not necessarily successive).
}

intrinsic one; rather, it results from specific epistemological options which remain the entire responsibility of their authors, today as well as in the past.

In the history of archaeology, the inevitability of the relation between science and politics may be nothing more than an artefact of the reconstruction. As scholars adopt almost exclusively the national scale as an a priori framework for research, they are all too often led to overestimate the importance and breadth of nationalist components. What is more, this overestimation also results from the reductionist nature of their internalist perspective, which gives only a partial image of the development of archaeology. In fact, and in contrast to the linear schemes of presentist historiography, the origins of archaeology are multiple and diverse. If we only look at prehistory, we can say that in its present form it comes from a fusion of distinct fields and research traditions. At its origins, prehistoric research was carried out by scholars from extremely diversified disciplinary backgrounds. Depending on whether they were historians, philologists, ethnographers, palaeontologists or geologists, the material remains of the human past were accordingly subjected to quite diverse interrogations. Clearly, these scholars did not pursue tho same epistemological objectives.

\section{Two radically different research programmes}

At the roots of prehistoric archaeology, one can actually distinguish two fundamentally different research programmes. ${ }^{3}$ The first was the antiquarian approach, which mainly consisted of illustrating the life, manners, customs and beliefs of ancient peoples. This antiquarianism leant back on concepts inherited from the Enlightenment, where the notion of 'peoples' was certainly not the same as the one invoked by 19th-century nationalism. However, the ethnicism inherent to the antiquarian tradition was in some way destined to contribute to the emergence of these nationalisms, and eventually to benefit from them.

3 Amidst the wealth of cognitive influences characteristic of the pre-disciplinary phase, these two approaches did not constitute two homogeneous and strictly defined camps. They should rather be considered as tendencies, whose differences and contradictions were not always consciously appreciated by their proponents ( $c$. Coye 1997). 
Although this antiquarian programme is invariably presented as the foundation of the discipline, it constitutes only one of its pillars. The other rescarch programme, which can be labelled 'evolutionist', holds a similarly important place in the development of prehistoric: archaeology but has been almost entirely overlooked in most historical studies. And in the rare cases where it has been mentioned, its importance has generally been denied. This ignorance may seem surprising at first sight, but it results from the same presentism underlying most research in the history of archaeology. ${ }^{4}$ Indeed, this evolutionist approach was established by naturalists who, in contrast to the antiquarians, had a well-defined professional status. Goologists, botanists or physiologists formally belonged to well-established scientific frameworks which were eventually rejected by prehistoric archaeology during its own process of disciplinary formation.

Taking into account the importance of this evolutionist programme in the origins of prehistory will clearly have considerable repercussions on the issue of nationalism. Evolutionism primarily sought to demonstrate the process of human evolution in its relation to the social and natural milieu. With its predominant focus on such topics as technology, 'industrial' dynamic, exchange and trade, this archaeology defined cultures as the product of an interaction between society and environment. As a corollary, it was not very much concerned with ethnic distinctions - and thus by and large remained separate from all sorts of nationalist concerns.

\section{From research object to discipline: the role of institutions}

General reviews of the history of archaeology (e.g. Trigger 1989; Schnapp 1996) have shown how material remains from the prehistoric past have evoked curiosity and interest throughout the ages. Up until the 19th century, however, this interest remained firmly integrated in other fields of knowledge and thought. In medieval graves, prehistoric flints were sometimes in-

4 This ignorance is probably also due to the position taken by historians of archaeology within the contemporary theoretical debate in archaeology. Disavowing the New Archaeology which was regarded, rather simplistically in fact, as a legacy of 19th-century evolutionism, they may believe that this evolutionist research programme has no relevance in their historical reconstructions. cluded as funerary gifts that accompanied the dead in the hereafter. From the Renaissance onwards, European antiquarians collected prehistoric artefacts in their cabinets and displayed them with fossils and minerals. During the 17 th and 18th centuries, prehisloric objects began to be regarded as witnesses of dark ages and forgotten civilizations that had once existed, well before history. But we have to wait until the beginning of the 19th century to see these materials integrated in a global vision of the history of humanity, the so-called Three-Age System, which some scholars have not hesitated to call the first 'paradigm' of archaeology (Rodden 1981). Since the works of the Scandinavian antiquarians, prehistory had really begun to be considered as a proper research field of its own. Nonetheless, those studying prehistory did not limit themselves to this topic as such. At that time, prehistory was still part of the study of 'national antiquities', a research field which covered a much larger theme, stretching at least as far as medieval epigraphy.

In fact, it was only with the establishment of deep human antiquity, particularly with the acceptance of the discoveries of Boucher de Perthes from 1859 onwards, that some scholars started to consider that the study of human societies (from the origins of humanity to the appearance of written sources) constituted a homogeneous research field in its own right. Freed from the tutelage of geology and palaeontology on the one hand, and of history and historical archaeology on the other, prehistoric archaeology could now become an autonomous branch of scientific research. In these conditions, specific institutions for prehistoric: rosearch had to be established (Kaeser forthcoming). Starting as an idea, the concept of prehistory could only gain body and form through dedicated institutions.

To understand better the birth of our discipline, it will not do to focus exclusively on 'pioneers', 'forerunners', their thoorios and their interpretations. These cognitive processes have to be replaced within the context of the institutions which allowed the social construction of the prehistoric discipline. The history of institutions alone allows us to link the study of sociohistorical clements on the one hand with the more cognitive factors on the other; only such a history allows us to go beyond the rigid dichotomies between sociology of science and history of ideas (Chapman 1989; Richard 1992; 
Blanckaert 1995). Last but not least, for archaeologists interested in the history of research, the history of institutions has the additional advantage of solving another sterile opposition, that between internalist and externalist history.

\section{Constructing the discipline: the International Congress of Prehistory}

In the second half of the 19th century, the various research undertakings within the field of prehistory did not have yet a solid institutional apparatus to rest on. Throughout Europe, the first academic chairs only began to appear at the turn of the century. And even if prehistory had sometimes been the subject of university teaching since the 1860s, these remained occasional courses resulting from the personal interest of professors in history, art history, anthropology, palacontology or geology. The first specifically prehistoric institution was in fact a journal: the Materiaux pour l'histoire positive et philosophique de l'homme. Launched in 1864 by Gabriel de Mortillet, this journal had considerable success that went well beyond France (Richard 1992). Two years later, an analogous initiative emerged in Germany, the Archiv für Anthropologie, soon to be followed by the Bullettino di Paletnologia italiana. So far as museums were concerned, however, nothing noteworthy seemed to have happened then at this time. Many did collect prehistoric remains, but they were not specialized in this field and simply accumulated the presentation of prehistoric times with displays on national history, modern 'primitive' peoples or natural history. ${ }^{5}$

In a very general sense, then, the object of prehistoric research remained associated with the broader realms of history and of 'national antiquities'. It was only in the early 20 th century that in most European nations the first strictly prehistoric societios and institutions were created.

5 In this respect, though, special mention should be made of the role of the Musée des antiquités nationales (MAN) at Saint-Germain-en-Laye, opened in 1867 (Larrouy 1998). Growing away from Napoléon IIl's original plan of a museum dedicated to Gaulish, Roman, Phoenician and Greek antiquities, the MAN granted, under the influence of Mortillet, considerable space to prehistory, presented as a specific field of archaeological study. Together with the prehistoric display set up by the same Mortillet within the precincts of the Exposition universelle in that same year 1867 (Müller-Scheessel 2001), the foundation of the MAN is closely related to that of the International Congress of Prehistory.
However, while the process of institutionalization was extremely late on the regional and national levels, it had in fact already begun much earlier, albeit on a much larger scale. In effect, the first specifically prehistoric association was an international one: the International Congress of Prehistory (Congrès international d'anthropologie et d'archéologie préhistoriques, CIAAP), founded in 1865, almost four decades before any national body emerged. As we will see (and cf. Kaoser 2001), this institution exerted a seminal influence on the discipline in the making.

\section{Internationalism and its effects on the epistemology of prehistory}

The international character of the first institutionalization of prehistory was not accidental, but rather resulted from a combination of several structural factors. Among these were a number of circumstantial factors. For one, the founding fathers of the International Congress of Prehistory, Edouard Desor (Figure 1) and Gabriel de Mortillet, were both polyglots who could call upon some fairly extensive networks of international contacts and friendships. ${ }^{6} \mathrm{As}$ well, this international scale corresponded perfectly well with their cosmopolitan ideal of a global republic of scholars - an ideal they shared with most of their colleagues (Rasmussen 1997). Finally, this scale enabled them to smoothly circumvent the manifest resistance of national scientific institutions (FIGURE 2).

These circumstantial factors, however, do not suffice by themselves to explain the choice of an international scale. On closer inspection, it becomes clear that this choice resulted from a deliberate attempt to remove the advocates of the antiquarian tradition from the field of prehistoric research. Indeed, inasmuch as the reference framowork of antiquarian research was regional or national, the universalist heuristic perspective adopted by the international congresses stripped their line of research of its relevance. The form of the new institution was quite dissuasive for the antiquarians. Even though their overall numbers were considerable, the participation of antiquarians in the CIAAP remained therefore very minimal and was hardly noted.

Clearly, this eviction of the antiquarians had important consequences on the epistemologi-

6 On de Mortillet, $c f$. Hammond 1980; Richard 1999 and this valume; on Desor, $c f$. Kaeser forthcoming. 


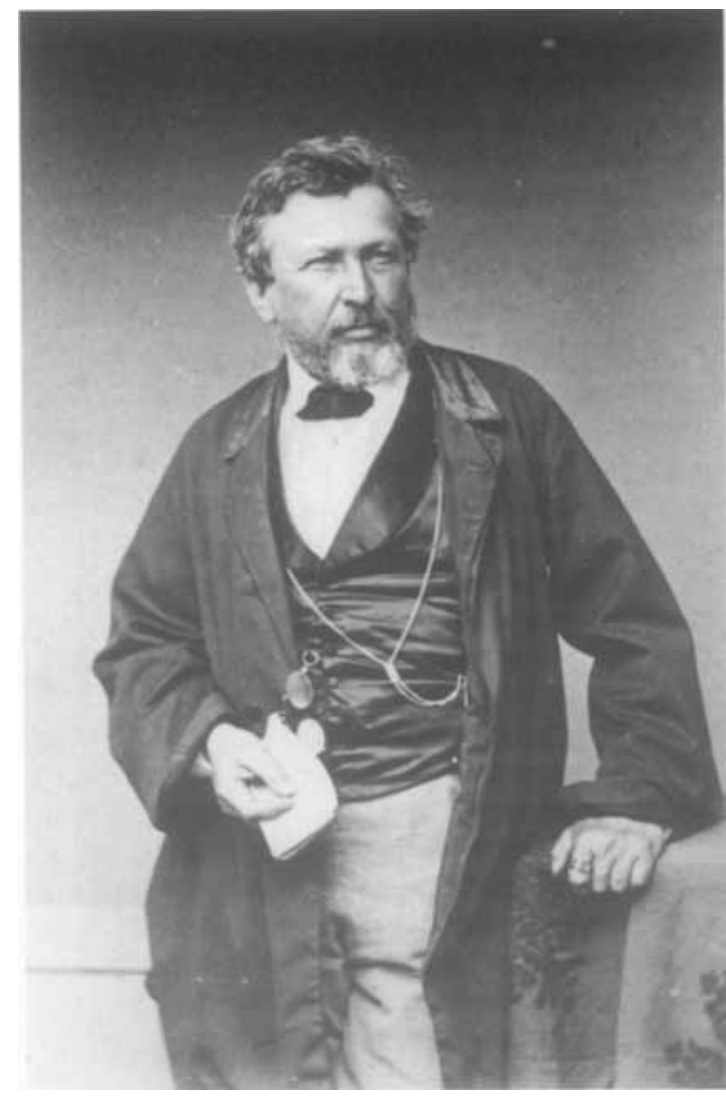

FiguRE 1. Edouard Desor (1811-1882), the initiator of the International Congress of Prehistory. Archives Combe-Varin, Bibliothèque Publique et Universitaire de Neuchâtel. Desor, a professor of geology in Neuchâtel, discovered prehistory while travelling in Scandinavia in 1846. Especially known for his research on palafitic (lakc) dwellings and his division of the Iron Age into the Hallstall and La Tene periods, Desor played an important role in the politics of science in Switzcrland. A Swiss citizen born a German in a French-speaking community, Desor lived six years in Paris and five in the United States, had strong global conlacts, and was an enthusiastic advocate of the cosmopolitan ideals which pervaded the foundation of the International Congress of Prehistory (see Kaeser, forthcoming).

cal interpretation of prchistoric research. From now on, one could finally establish the methodological principles of prehistoric research. Each suggestion derived from learned history, biblical texts, mythology, linguistics or philology could be excluded. According to the resolutely scientistic perspective adopted, material remains of the past had from now on to speak for themselves. And to prompt them into speech, the prehistorian was restricted to using the conceptual tools of stratigraphy, technology and typology (see Schnapp 1996 and this volume).

At the same time, the adoption of this universalist heuristic framework helped to align prehistoric research with evolutionism. In contrast to the antiquarian programme which was primarily concerned with defining the diachronic permanence and the essentialist features of individual cultures, peoples and 'nations', the evolutionist programme sought to characterize the successive stages of the development of civilisation. Now, because this explanatory framework of evolutionism sought to be universal and thus valid for humanity as a whole, the framework under which these studies were conducted could in turn only be international.

\section{International foundations for the institutionalization of prehistory}

Over several decades, the International Congross of Prehistory enjoyed considerable success. The leading scholars in prehistoric research made sure they regularly attended its meetings and contributed to its sessions. But the CIAAP did not simply gather the principal authorities in the field: each meeting also welcomed as many as several hundred participants - fellow professionals in neighbouring disciplines (mainly natural sciences), and also a wide range of more or less specialized amateurs. The CIAAP covered most of Europe in its venues, though it never met in the German Reich (MüllerScheessel forthcoming). Initially schoduled every year, the meetings became less and less frequent: after its foundalion in La Spezia (1865), the Congress met in Neuchâtel (1866), Paris (1867), Norwich and London (1868), Copenhagen (1869), Bologna (1871) (FIGLRE 3), Brussels (1872), Stockholm (1874), Budapest (1876), Lisbon (1880), Paris (1889), Moscow (1892), Paris again (1900), Monaco (1906), and Geneva (1912). Obviously, this decreasing frequency testifies to a manifest decline, anticipating a termination of activities after the first World War (MüllerScheessel forthcoming). Reasons for this decline are diverse, but it is undeniable that doubts over the cosmopolitan ideals of the 1860 s and the strengthening of fin-de-siècle nationalist beliefs (see Richard, this volume) contributed to the fate of the CIAAP.

Ideological reasons aside, the decline of the CIAAP proceeds above all from internal causos: 

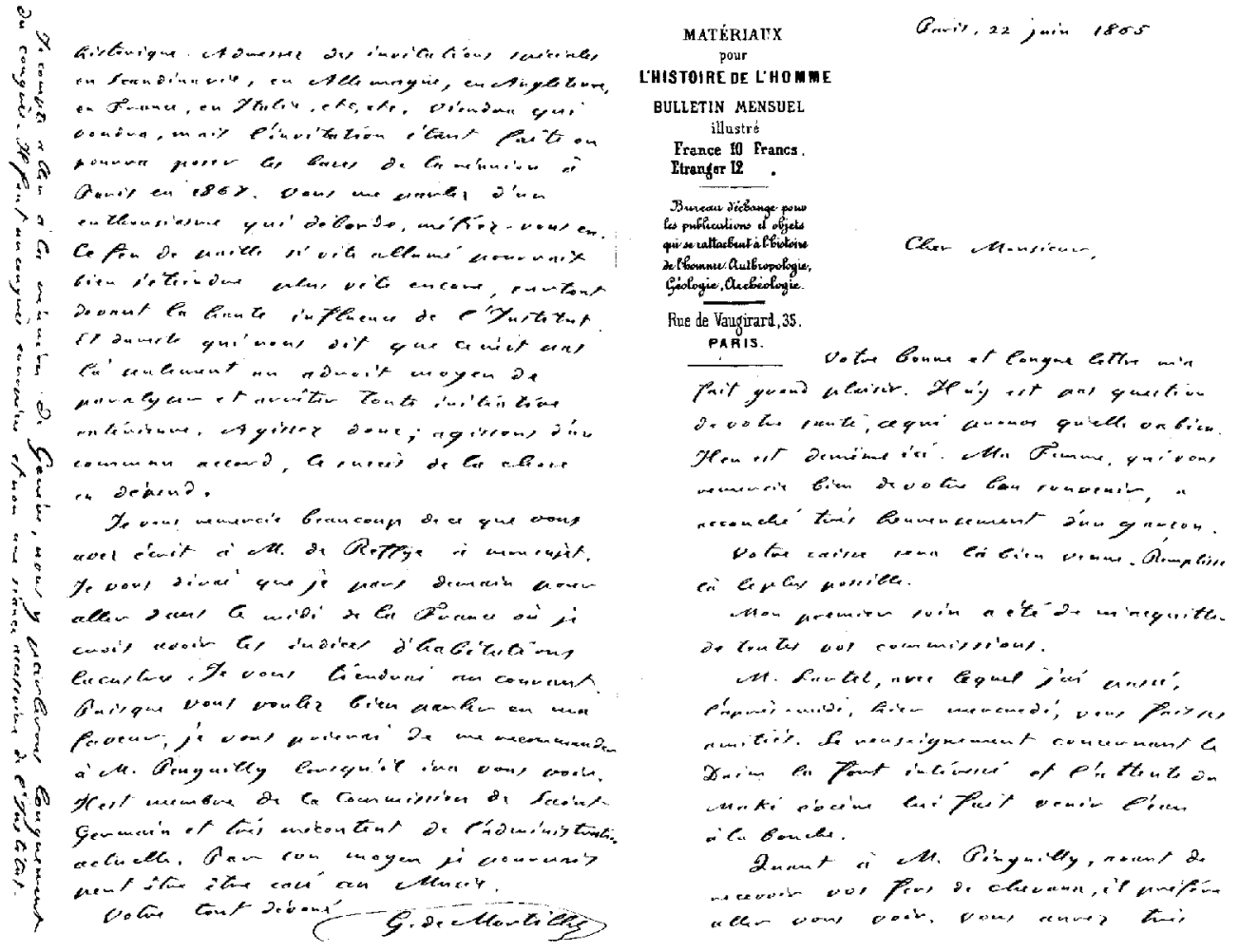

FIGURE 2. Letter from Gubriel de Mortillel to Edouard Desor, 22 June 1865 (Dosor Papers, State Archives Neuchattel, Switzerland). Contrary to its official history, the foundation of the International Congress of Prehistory was the result of an individual's initiative. The Swiss Edouard Desor first suggested the organization of a vast archaeological display at the International Exhibition of Paris (1867). In his mind, such a display would provide a good opportunity to gather all scholars involved in prehistoric research throughout the world - a perfect excuse for setfing up an international congress dovoted to these particular studies. As it transpires in this letter, Desor could count on the support of de Mortillet and his periodical Matériaux pour l'histoire positive et philosophique de l'homme. As a matter of fact, they both strived to protect the project from being taken over by the French imperial, conservative sciontific establishment: the representatives of official science remained sceptical towards the reality of prehistory, and tried to turn Desor's idea into an exclusively ethnological celebration of French imperialism. This was the reason why Desor and de Mortillet surreptitiously founded the Congress in Italy, and why they held its first session in Switzerland: the board of the Paris meeting was elected by the participants of the meeting of Neuchatel, instead of being appointed by the French imperial authorilies.

Extracts: Mortillet to Desor, 22 June 1865

About the 'Exposition universelle' .. . Maintenant comme il faut rendre à César ce qui est à César, dans ma chronique du mois, je vais parler de votre proposition.

Comme je viens de vous le dire l'exposition est décidée. C'est bien. Elle se fera. Mais il faut qu'elle porte ses fruits. Or elle ne peut être d'une grande utilité qu'autant qu'on y adjoigne un Congrès spécial. Le complément de votre projet est indispensable. C'est à vous a mener la chose à bonne fin. Vous pouvez disposer de moi et de mon journal. Donnez donc suite à votre idée d'avoir l'année prochaine la Société Helvétique à Neuchâtel. Organisez une section anté-historique. Adressez des invitations spéciales en Scandinavie, en Allemagne, en Angleterre, en France, en Italie, etc. etc. Viendra qui voudra, mais l'invitation étant faite on pourra poser les bases de la réunion à Paris en 1867. Vous me parlez d'un enthousiasme qui déborde, méfiez-vous en. Ce feu de paille si vite allumé pourrait bien s'éteindre plus vite encore, surtout devant la haute influence de l'Institut [the Academy of Sciences]. Et du reste qui nous dit que ce n'est pas là seulemont un adroit moyen de paralyser et arrêter toute initiative extérieure. Agissez donc; agissons d'un commun accord, le succès do la chose en dépend.

Added along the left-hand margin: Jo compte allor à la réunion do Genève, nous y parlerons longuement du congrès. Il faut un congrès européen et non une séance accessoire de l'Institut. 


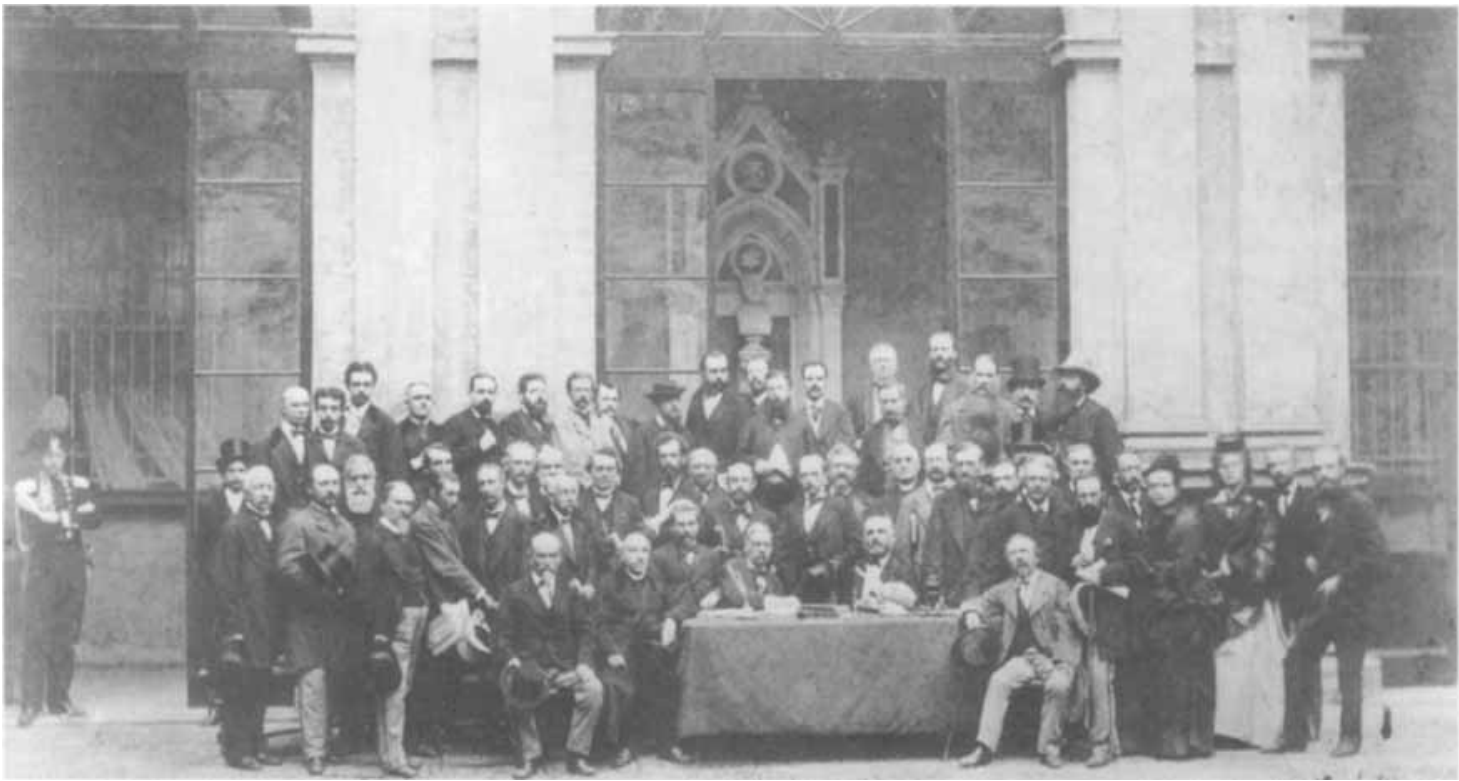

FIGURE 3. Participants of the 5th meeting of the International Congress of Prehistory in Bologna (1871). Museo Civico Archeologico, Bologna.

the international meetings suffered from the fact that the emergent structures for prehistoric research were increasingly national. Ironically, this national orientation can be considered as the indirect outcome of the CIAAP: once the institutionalization of prehistory had been successfully completed on the international level, the fruitfulness of a similar action on the national level had become clear, especially now that the research field had acquired its scientific credibility.

Growing sensibility towards the archaeological heritage led to the constitution of many public institutions responsible for its excavation and preservation - a process which eventually fostered a starting professionalization. In the museums, prehistory progressively emancipated itself from the wider domains of ethnology, national antiquities, or natural history. Consequently, the new, self-confident communities of prehistorians undertook to organize themselves: in most European countries, national societies were being founded to defend the interests of prehistory and prehistorians. The success of its international institutionalization made way for the constitution of a full fledged discipline. From then on, prehistory could properly enter the universities, where chairs and independent departments came into being.
In a certain sense, then, the International Congress of Prehistory had accomplished its mission. Whereas scientific exchanges had previously been very difficult, the congress largely facilitated the dissemination of updated archaeological information. The CIAAP has also initiated or witnessed several debates which proved instrumental in developing a set of shared rules and methods to be adopted by members of a self-recognized scientific community with its distinctive and consistent field of study.

\section{Epilogue}

Today, throughout the world, prehistoric research is organized on a national or regional scale. In this respect at least, things have clearly changed since the foundation of the CIAAP. The application of the concept of 'culture' in early 20th-century anthropology contributed to undermine further the evolutionist programme of the early prehistorians. Nevertheless, whon the institutional history of the field is taken into account, one must recognize that originally prehistoric archaeology had international roots. It can thus be concluded that our discipline is not intrinsically nationalist. This should not put our minds at rest, however, since the study of the disciplinary past should never serve to absolve us of the present. At the end of the day, history 
should make us aware that as prehistorians, our present relation to nationalist ideologies does not depend upon inherited disciplinary principles, but results from the epistemological orientations that each one of us freely chooses to follow.

\section{References}

BLANCKAERT, C. 1995. Fondements disciplinaires de l'anlbropologie française au XIXe sic̀cle. Pcrspectives historiographiques, Politix 29: 31-54.

CHAPMAN, W.R. 1989. Toward an institutional history of archaeology: British archaealogists and allied interests in the 1860 s, in A.I. Christenson (ed.), Tracing archatology's past. The historiography of archaeology: 151-62. Carbondale (IL): Southern Illinois University.

COYE, N. 1997. La préhistoire en parole et en acte. Méthodes et enjeux de lo pratique archéologique, 1830-1950. Haris: LHarmattan.

DIAZ-ANDREU, M. \& T. CHAMPION. 1996. Nationalism and archaeology in Europe. London: University College London Press.

GRAMSCH, A. 1999. Scientific of political 'reflexiveness': archaeology, nationalism, and europeanism, European Journal of Archaeology 2:117-24.

2000. 'Reflexiveness' in archaeology, nationalism, and Europeanism, Archaeological Dialogues 7: 4-19.

HAMILAKIS, Y. 1996. Through the looking glass: nationalism, archaeology and the politics of identily, Antiquity 70 : 975-8.

Hammund, M. 1980. Anthropology as a weapon of social combat in late-ninetecnth-century France, Journal of the History of the Behavioral Sciences 16: 118-32.

KAIsER, M.-A. 2000a. Nationalisme et archéologie: quelle histoire?, Revue d'Histoire des Sciences Humaines 2: 15562.

$2000 b$. Talking about readings of the past: a delusive debate, Archaeological Dialogues 7: 35-7

2001. L'internationalisation de la préhistoire, une manoeuvre tactique? Les conséquences épistémologiques de la fondation des Congrès internationaux d'anthropologie ot d'archéologie préhistoriques, in C. Blanckaert (ed.), Les politiques de l'anthropologie. Discours et pratiques en France (1860-1940): 201-30. Paris: L'Harmattan.
Acknowledgements. Translation by David Van Reybrouck, whom I would also like to thank, as well as Nathan Schlanger, for their helpful suggestions. I am grateful to Claude Blanckaert, loo, who encouraged me to study the "internationalization' of prehistoric science.

Forthcoming. L'univers du préhistorien. Science, foi et politique dans l'ceurre et la vie d'Edouard Desor (18111882). Paris: L'Harmattan.

KoHL, Ph.L. 1998. Nationalism and archaeology: On the constructions of nations and the reconstructions of the remote past, Annual Review of Anthropology 27:223-46.

LARROIYY, P. 1998. Les premières années du Musée des Antiquités Nalionales, Antiquités nalionales 30: 197-206.

MÜLLER-SCHEESSEL, N. 2001. Fair prehistory: archaeological exhibits at French Expositions universelles, Antiquity 75: 391-401.

Forthcoming. ' . . dem Romanismus entgegentreten': Nationul animosities among the participants of the Congrès inlernational d'authropolugic et d'archéologie préhistoriques.

RASMUSSEN, A. 1997. L'amitié, une valeur scientifique. Les amities internationales des savants au tournant du siècle, Jean faurès: Cahiers trimestriels 143: 77-95.

RIC:HARD, N. 1992. L'instilutionalisation de la préhistoire, Communications 54: 189-207.

1999. Gabriel de Mortillet, 1821-1898, in T. Murray (ed.) Encyclopodia of Archacology. The Great Archocologisis: 93-107. Sunta Barbara (CA): ABC-Clio.

RoDden, J. 1981. The development of the Three Age System: Archaeology's first paradigm, in G. Daniel (ed.), Towurds a history of archaeology. Being the papers read at tho first Conference on the History of Archaeology in Aarhus, 29 August-2 September 1978: 51-68. London: Thames \& Hudson.

SCHNAPP, A. 1996. The discovery of the past. London: British Museum Press.

Tricrer, B.G. 1989. A history of archaeological thought. Cambridge: Cámbridge University Press.

WELL, S. 1999. The Congress of Anthropology and Archaeology in Copenhagen 1869 - behind the stage, Antiquity $73: 136-42$

\title{
Archaeological arguments in national debates in late 19th-century France: Gabriel de Mortillet's La Formation de Ia nation française (1897)
}

\author{
NATHALIE RICHARD*
}

Key-words: Gabriel de Mortillet, late 19th-century france, Formation de la nation française, Germany, nationalism, linguistics, raciology, history of archaealogy

Chauvinist reactions were rife in late 19th-century France, following the 1870 defeat to Prussia, the unification of Germany and the annexation of Alsace and part of Lorraine to the new empire. Besides their political manifestations, as in the creation of the Ligue des patriotes in 1882,

* Université Paris 1-Panthéon-Sorbonne, Centre d'histoire des sciencos et des mouvements intellectucls, 9 rue Malher, 75004 Paris, France. 